\title{
EVALUATION OF THE GROWTH PERFORMANCE OF BROILER CHICKS FED ON PLANT DIETS SUPPLEMENT ED WITH SOME FEED ADDITIVES.
}

\author{
Osman, A. M. A. 1; M. A. H. Soliman'; H. H. Hassanein ${ }^{2}$ and
}

A. A. A. Abd EL-Warth ${ }^{2}$

1- Animal Prod. Dept., Fac. of Agric., Minia Univ., Minia

2- Animal Prod. Dept., Fac. of Agric., South Valley Univ., Qena

\begin{abstract}
A total number of 360 , unsexed one-day old Hubbard broiler chicks were randomly distributed into 12 groups with 3 replicates of 10 chicks each and used in a factorial experiment [3 diets $\times 4$ feed additives (probiotics)]. Two control diets (one starter and another grower) were formulated from plant-origin ingredients to meet the major nutrient requirements of broiler chicks. Other two starter and two grower diets were formulated to have $2 \%$ less CP but adequate ME (low-CP diets) or less ME by $200 \mathrm{kcal} / \mathrm{kg}$ but adequate CP (low-ME diets).

Both starter and grower diets were supplemented with or without $0.1 \%$ Bio-Min (as a microbial growth promoter) or $0.03 \%$ Ronozyme (as enzymatic growth promoter) or $0.1 \%$ Super-Bio-Action (as a microbial and enzymatic growth promoter). Birds received the experimental diets up to 6 weeks of age. The criteria of response were the performance of chicks for weight gain and feed conversion, some carcass and digestive tract measurements, and economic efficiency.

The results revealed the following

- Broiler chicks fed on the low-ME diets achieved heaviest body weight at 6 weeks of age and body weight gain during the period from 3 to 6 and $0-6$ weeks of age.

- Addition of probiotics into broiler chick diets improved $(P \leq 0.05)$ the chicks, body weight gain, during starting period (0-3 weeks of age) and during the whole experimental period ( 0 to 6 weeks of age).

- Broiler chicks fed on the low ME diet consumed the greatest $(P \leq 0.05)$ amount of feed during the growing period ( 3 to 6 weeks of age) and entire experimental period (0 to 6 weeks of age).

- Birds fed on the low-ME or low-CP diets exhibited a significantly $(P \leq 0.05)$ inferior feed conversion during the starting period compared to their control counterparts, but this significant difference was disappeared during the growing and entire experimental period.

- Probiotics supplementation improved $(P \leq 0.05)$ the feed conversion during starting, growing and entire experimental periods.

- Neither diet nor probiotics had significant effect on viability of chicks during the entire experimental period.

- Broiler chicks fed on the low-ME diets achieved a lower $(P \leq 0.05)$ cost of feed/kg gain compared to those fed on the low-CP diets. However, selling price/bird and economic efficiency were the highest $(P \leq 0.05)$ by feeding the low-ME diets. Economic efficiency was also improved by feed supplements used.

- Dietary treatments had insignificant effect on dressing \%, while broiler chicks fed on the low-CP diets had the highest $(\mathrm{P} \leq 0.05)$ abdominal fat \% at marketing age.

- Probiotics supplementation improved $(P<0.01)$ carcass weight, while dressing, abdominal fat and giblets percentages were not significantly influenced.

- Broiler chicks fed on the low-ME diets recorded the lowest $(P \leq 0.05)$ relative length of small intestine, cecum, large intestine and relative weight.

- Probiotics had negligible effect on some digestive tract measurements.
\end{abstract}


Osman, A. M. A. et al.

\section{INTRODUCTION}

Feeding cost represents the major component of the cost of poultry production. Many attempts have been made to decrease the cost of feeding of different species of poultry. These attempts focused on replacing the more expensive and less available feedstuffs by cheaper and more abundant ones, and the use of more balanced diets supplemented with synthetic amino acids or growth promoters, and thus increasing the efficiency of feed utilization.

Recently, many countries have began to prevent the application of chemical antibiotics; as growth promoters, because of their side effect on both birds and humans. Therefore, most of poultry producers tended to use probiotics as safe alternative growth promoters.

Nowadays, there is a tendency to compose poultry diets of plant materials, mainly cereals and vegetable protein. Most of the feed ingredients contain less-or non-digested part (cellulose, xylose, arabinose,...) and some anti-nutritive factors, which inhibit feed utilization and birds performance. Part of this adverse effect can be overcome by dietary enzyme supplementation which has been shown to lower the viscosity of intestinal contents and thus improving digestibility of starch, protein and fat by broiler chicks fed wheatcontaining diets (Annison and Choct, 1991; Bedford, 1995). Moreover, the beneficial effect of dietary supplementation with probiotics which contain Lactobacillus acidophilus, on the performance of broiler chicks may be mediated by a direct antagonistic effect against pathogenic micro-organisms, resulting in a decrease in their population (Hentges, 1983) or by stimulation of immunity (Umesb, 1999).

The present work was carried out to study the extent to which the growth performance, carcass traits and/or some digestive tract measurements in broiler chicks can be affected by dietary supplementation of plant-protein diets with some probiotics.

\section{MATERIALS AND METHODS}

This study was carried out at the Poultry Farm, Department of Animal Production, Faculty of Agriculture, South Valley University. A total number of 360 , one-day old Hubbard broiler chicks were used in this study. Chicks were purchased from Qena Poultry Station and brooded in two-tier wire-floored battery, located in windowless house under same managerial conditions. Chicks were randomly distributed into 12 groups ( 3 diets $X 4$ feed additives) with 3 replicates of 10 chicks each. Average initial body weights of chicks in all treatments were almost similar. Two control diets (one starter and another grower) were formulated from plant-origin ingredients to meet the major nutrient requirements of broiler chicks, as recommended by the National Research Council (NRC, 1994). Other two starter and two grower diets were formulated to have $2 \%$ less protein, but adequate level of metabolizable energy (ME) and termed as low-crude protein diets (low CP) or less ME by about $200 \mathrm{Kcal} / \mathrm{kg}$ diet, but adequate level of $\mathrm{CP}$ and assigned as low-ME diets. All diets were formulated to have similar levels of lysine and sulphur 
amino acids (Table 1). All chicks had a full access to feed and water during the experimental period.

Table (1) Composition of the experimental diets:

\begin{tabular}{|l|c|c|c|c|c|c|}
\hline \multirow{2}{*}{ INGREDIENTS \% } & \multicolumn{2}{|c|}{ STARTER DIETS } & \multicolumn{3}{c|}{ GROWER DIETS } \\
\cline { 2 - 7 } & Contro & $\begin{array}{c}\text { Low } \\
\text { Protein }\end{array}$ & $\begin{array}{c}\text { Low } \\
\text { Energy }\end{array}$ & Control & $\begin{array}{c}\text { Low } \\
\text { Protein }\end{array}$ & $\begin{array}{c}\text { Low } \\
\text { Energy }\end{array}$ \\
\hline Yellow corn & 53.20 & 60.00 & 57.15 & 57.15 & 63.94 & 61.60 \\
Soybean meal,44\%CP & 31.10 & 25.23 & 31.10 & 26.00 & 20.13 & 26.00 \\
Corn gluten meal & 8.00 & 8.00 & 7.50 & 8.00 & 8.00 & 7.30 \\
Vegetable oil & 3.83 & 2.59 & ---- & 4.74 & 3.50 & 1.02 \\
Dicalcium phosphate & 1.70 & 1.70 & 1.65 & 1.75 & 1.76 & 1.70 \\
Limestone & 1.50 & 1.60 & 1.50 & 1.50 & 1.60 & 1.52 \\
Common salt & 0.10 & 0.10 & 0.10 & 0.10 & 0.10 & 0.10 \\
Vit\&min.mix & 0.25 & 0.25 & 0.25 & 0.25 & 0.25 & 0.25 \\
Lysine & 0.14 & 0.29 & 0.13 & 0.27 & 0.42 & 0.27 \\
Methionine & 0.18 & 0.24 & 0.18 & 0.24 & 0.30 & 0.24 \\
Total & 100,00 & 100,00 & 100,00 & 100,00 & 100,00 & 100,00 \\
Calculated analysis & & & & & & \\
Crude protein & 23.01 & $\mathbf{2 1 . 0 0}$ & 23.08 & 21.09 & $\mathbf{1 9 . 0 9}$ & 21.05 \\
Metabolizable energy; & 3110 & 3105 & $\mathbf{2 9 0 2}$ & 3209 & 3203 & $\mathbf{3 0 0 4}$ \\
ME(kcal ME/ kg diet) & & & & & & \\
Calcium; \% & 1.00 & 1.03 & 1.00 & 1.00 & 1.00 & 1.00 \\
Avail. P; \% & 0.45 & 0.45 & 0.45 & 0.45 & 0.45 & 0.45 \\
Lysine; \% & 1.20 & 1.20 & 1.20 & 1.20 & 1.20 & 1.20 \\
Methionine+cys; \% & 0.93 & 0.93 & 0.93 & 0.93 & 0.93 & 0.93 \\
\hline
\end{tabular}

Each diet was supplemented with Vit. \& Min. Mix : Each 2.5 kg contains, Vit. A 10 MIU; Vit. $\mathrm{D}_{3} 2$ MIU; Vit. E $10000 \mathrm{mg}$; Vit. K3 $1000 \mathrm{mg}$; Vit. B1 1000 mg ; Vit. B2 5000 mg ; Vit. B6 $1500 \mathrm{mg}$; Biotin $50 \mathrm{mg}$; BHT $10000 \mathrm{mg}$; Pantothenic acid $10000 \mathrm{mg}$; Folic acid 1000 $\mathrm{mg}$; Nicotinic acid $30000 \mathrm{mg}$; Mn $60 \mathrm{~g}$; Zn $50 \mathrm{~g}$; Fe $30 \mathrm{~g} ; \mathrm{Cu} 4 \mathrm{~g}$; I $3 \mathrm{~g}$; Se $0.1 \mathrm{~g}$; and Co $0.1 \mathrm{gm}$.

Both starter and grower diets were supplemented with or without BioMin (1 kg/ton feed); as a microbial growth promoter, which contain Entercocci faecium, fructo-oligosaccharide, piece of cell wall of bacteria and a mixture of algaeor Ronozyme ( $300 \mathrm{~g} /$ ton feed), as an enzymatic growth promoter containing glucanase and pectinase or Super Bio-Action (1 kg/ton feed), as a microbial and enzymatic growth promoter. The applied level of such probiotics and enzyme products was recommended by the manufacturer. The composition of Super Bio- Action is presented in Table 2.

Birds in each replicate were weighed at 21 and 42 days of age and the feed consumed was also recorded on a replicate group basis. Feed conversion (grams feed/gram of gain) was calculated for the different experimental periods. Mortality was monitored and recorded daily throughout the entire experimental period. Cost of one kilogram feed for different diets, cost of feed $/ \mathrm{kg}$ gain and the cost of feed/bird were calculated on the basis of the prevailing price of feed ingredients in the local market. The absolute net return was calculated as selling price/bird minus cost of feed/bird. The relative economic returns for the experimental birds were calculated relative to their control counterparts.

At 6 weeks of age (end of the experiment), three birds from each treatment with an average body weight of their respective treatment were slaughtered. Eviscerated carcasses were individually weighed and dressing 
Osman, A. M. A. et al.

percentage was calculated (weight of carcass + giblets + abdominal fat/preslaughter weight $\times 100$ ).

Table (2) Composition of Super Bio - Action / kg of the product.

\begin{tabular}{|l|c|c|}
\hline Items & \multicolumn{2}{|c|}{} \\
\hline Saccharomyces cerevisiae & 1.25 & Trillion CFU \\
\hline Bacillus subtillus & 500 & million CFU \\
\hline Protease & 125 & Unit \\
\hline Amylase & 125 & Unit \\
\hline Cellulase & 10 & Unit \\
\hline Lipase & 5 & Unit \\
\hline Pure calcium & 180 & $\mathrm{Mg}$ \\
\hline Active dry yeast & 125 & $\mathrm{Mg}$ \\
\hline Malted Barley & 50 & $\mathrm{Mg}$ \\
\hline Aspergillus oryzae & 25 & $\mathrm{Mg}$ \\
\hline Cane molass & 50 & $\mathrm{Mg}$ \\
\hline Fermented corn & 200 & $\mathrm{Mg}$ \\
\hline Fermented corn extract & 25 & $\mathrm{Mg}$ \\
\hline Oyster shells & 500 & $\mathrm{Mg}$ \\
\hline
\end{tabular}

Percentages of giblets (liver + gizzard + heart) and abdominal fat were also calculated relative to carcass weight. Some digestive tract measurements of the empty small and large intestines, duodenum and cecum were estimated relative to the starved body weight. The density of small and large intestine, duodenum and cecum were calculated as weight of part or organ (g) divided by its length in $\mathrm{cm}$. Data were subjected to analysis of variance using General Linear Model described in SAS User's Guide (SAS, 1994). The differences among the means of different treatments were compared using Duncan's multiple range test (at $5 \%$ level) only when $\mathrm{F}$-value was significant (Duncan, 1955).

\section{RESULTS AND DISCUSSION}

\section{1- Body weight and body weight gain:-}

\section{1-1-Effect of nutrient level:-}

Average weekly body weight and body weight gain of broiler chicks as affected by diet (energy and protein levels) and feed additives at different age intervals are presented in Table 3 . At 6 weeks of age and during the period from 3 to 6 and 0 to 6 weeks of age, the highest $(P \leq 0.05)$ body weight and body weight gain were attained by birds fed on the low-ME diets. However, those fed on the control or the low-CP diets achieved similar body weight and body weight gain during the same previously mentioned periods. The superiority in body weight and body weight gain achieved by birds fed on the low-ME diet represented about $29.4 \%$ and $50.8 \%$ and $30.5 \%$ over those of their control counterparts respectively, at marketing age (at 6 weeks of age). This superiority in body weight and body weight gain achieved by birds fed the low-ME diets was mainly related to their higher feed intake (Table, 4). In 
agreement with the present results, by Babu et al. (1986) who indicated that the reduction of protein by $2 \%$ units in the finisher diet did not adversely affect body weight. On the other hand, the present results disagree with those reported by Attia (1999), who indicated that body weight of broiler chicks responded positively with the increase of ME in the diets.

\section{1-2-Effect of feed additives:}

The addition of probiotics into broiler chick diets improved $(P<0.05)$ body weight at 3 and 6 weeks of age. Also, probiotics supplementation improved $(\mathrm{P}<0.05)$ body weight gain of broiler chicks during the starting period (0-3 weeks of age) and the whole experimental period (0-6 weeks of age), but their insignificant improving effects on body weight gain during the growing period ( $3-6$ weeks of age) were insignificant compared to those of the control birds (without probiotics). The relative improvements in 6-week-old body weight and body weight gain as a result of the addition of probiotics into broiler chicks diets were $14.92 \%, 12.04 \%$, and $11.73 \%$, and, $15.47 \%, 12.57 \%$ and $12.17 \%$ for Ronozyme, Biomin and Super Bio-Action for these two measurements, respectively. The beneficial effects of probiotics on body weight were associated with improvements in feed conversion ratios (Table, 4). Noy and Sklan (1994) indicated that the beneficial effects of dietary enzyme supplementation are likely related to an increase in the rate of diet digestibility and production of simple sugars (from fiber degradation). Also, Sklan (2001) suggested that the young bird might be limited in the types and amounts of enzymes necessary to utilize the high-carbohydrate and vegetable-protein diets at an early age, thus improving the nutrient digestibility. The dietary supplements used in the present study; as previously mentioned, either have enzymatic activity (such as Ronozyme) or have the ability to synthesize certain enzymes which can enhance the digestibility of nutrients.

Moreover, Watkins and Kratzer (1984) and Haddadin et al. (1997) found that Lactobacillus implantation in broiler chicks improved their weight gain and feed efficiency. Similarly Haddadin et al. (1997) indicated that the most likely explanation for the enhanced weight gain is that selected strain of $\mathrm{L}$. acidophilus colonizes the intestine of the chicks to varying degrees and once established, improves the bioavailability of essential nutrients such as the minerals, calcium and zinc. Also, the same organism causes a massive decline in the population of undesirable Gram-negative species like E. coli. Yeo and Kim (1997) showed that dietary probiotic suppressed the growth of harmful bacteria and increased the useful intestinal bacteria, which metabolize lactic acid and synthesize some vitamins. This effect along with a slight increase in feed intake may be responsible for the increased weight gain of birds fed such supplements under the condition of the present study.

\section{2-Feed intake and feed conversion}

\section{2-1-Effect of nutrient level:-}

Average cumulative feed intake and feed conversion ratio of broiler chicks as affected by diet and probiotics during starting (0-3 weeks of age) and growing (3-6 weeks of age) periods and the whole experimental period (06 weeks of age) are illustrated in Table, 4 . During the starting period, broiler chicks consumed similar amounts of feed. 
Osman, A. M. A. et al.

Table (3): Means of body weight gain of broiler chicks as affected by nutrient level and type of feed supplements during the experimental period.

\begin{tabular}{|c|c|c|c|c|c|}
\hline \multirow[t]{2}{*}{ TREATMENT } & \multicolumn{2}{|c|}{ Body weight } & \multicolumn{3}{|c|}{ Body weight gain } \\
\hline & $\begin{array}{c}3 \\
\text { Age in wks }\end{array}$ & $\begin{array}{c}6 \\
\text { Age in wks }\end{array}$ & $\begin{array}{c}0-3 \\
\text { Age in wks }\end{array}$ & \begin{tabular}{|c|}
$3-6$ \\
Age in wks
\end{tabular} & $\begin{array}{c}0-6 \\
\text { Age in wks }\end{array}$ \\
\hline Nutrient level & NS & ** & NS & $\star *$ & $\star *$ \\
\hline Control & 543.6 & $1296 b$ & 496.41 & $753.75 b$ & $1250 b$ \\
\hline Low-CP & 537.5 & $1262 b$ & 491.58 & $741.25 b$ & $1216 b$ \\
\hline Low-ME & 540.4 & $1677 a$ & 494.75 & $1136.75 a$ & $1632 a$ \\
\hline SE & 8.169 & 24.82 & 0.013 & 65.77 & 99.25 \\
\hline Feed additives & $* *$ & $\star *$ & ** & NS & $\star *$ \\
\hline Control & $485.1 b$ & $1287 b$ & $440.77 c$ & 822.88 & $1241 b$ \\
\hline Ronozyme & $579.4 a$ & $1479 a$ & $533.66 a$ & 900.00 & $1433 a$ \\
\hline Biomin & $548.9 a$ & $1442 a$ & $503.11 b$ & 893.33 & $1397 a$ \\
\hline Super Bio-Action & $547.6 a$ & $1438 a$ & $499.44 b$ & 892.77 & $1392 a$ \\
\hline SE & 9.432 & 28.66 & 8.201 & 10.22 & 28.75 \\
\hline Interaction & NS & NS & NS & NS & NS \\
\hline Control-Without & 475.0 & 1150 & 429.33 & 675.00 & 1104 \\
\hline Control-Ronozyme & 571.7 & 1332 & 526.33 & 760.00 & 1287 \\
\hline Control-Biomin & 573.3 & 1343 & 528.33 & 770.00 & 1298 \\
\hline Control-Superbio action & 554.3 & 1358 & 501.66 & 810.00 & 1312 \\
\hline Low-C.P-Without & 503.3 & 1160 & 458.00 & 723.33 & 1115 \\
\hline Low-C.P-Ronzyme & 590.0 & 1357 & 543.33 & 766.66 & 1308 \\
\hline Low-C.P-Biomin & 523.3 & 1252 & 477.00 & 728.33 & 1205 \\
\hline Low-C.P Superbio action & 533.3 & 1280 & 488.00 & 746.66 & 1235 \\
\hline Low-M.E-Without & 480.0 & 1550 & 435.00 & 1070.33 & 1506 \\
\hline Low-M.E-Ronozyme & 576.7 & 1750 & 531.33 & 1173.33 & 1705 \\
\hline Low-M.E-Biomin & 550.0 & 1732 & 504.00 & 1181.66 & 1685 \\
\hline Low-M.E-Superbio action & 555.0 & 1677 & 50.66 & 1121.66 & 1630 \\
\hline SE & 16.34 & 49.64 & 121.10 & 101.7 & 49.80 \\
\hline
\end{tabular}

For each main factor, means within the same column bearing different letter (s) differ significantly $(P \leq 0.05)$

However, significantly higher $(P<0.01)$ feed intakes were recorded for broiler chicks fed on low-ME diets during both the growing and the whole experimental periods. The relative increases in feed intake of broiler chicks fed on the low-ME diets were estimated to be 46.70 and $33.46 \%$ during the growing period and the entire experimental period, respectively, compared to those of the control birds. These results are in full agreement with the results reported early by Arram (1984) and Sohair (1984) who indicated that, broiler chicks fed the low energy diets achieved the highest feed intake. Moreover, Sailer (1985) indicated that feed intake was not significantly affected with reducing protein level up to 6 weeks of age in broiler chicks. On the other hand, the present results disagree with those reported by Garcia Neto et al. (2000) who indicated that feed intake increased as protein content in the diet was decreased.

Diet had significant effect $(P \leq 0.05)$ on feed conversion ratio only during the starting period; broiler chicks fed on the low CP or ME diets recorded inferior $(P<0.05)$ feed conversion ratio compared to those fed on the control diet at the previously mentioned period. From these results, it could be noticed that lowering the level of protein content or metabolizable energy in diets (by about $2 \%$ or $200 \mathrm{kcal} \mathrm{ME} / \mathrm{kg}$ ) less than the recommendations of NRC (1994) 
had no deleterious effect on feed conversion ratio of broiler chicks reared in windowless houses. These results coincide with the results reported by Moran (1979), who found insignificant differences in cumulative feed conversion ratio from 0 to 7 weeks of age in broiler chicks fed isocaloric grower rations of 24, 22 and $20 \%$ CP for males and 24, 20 and 16\% CP for females. Also, Daghir (1983) showed that, feed efficiency was not reduced by feeding either 15 or $12 \% \mathrm{CP}$ in the roaster diets, provided that these diets contain the recommended levels of methionine and lysine. Bougon and Menec (1986) fed broiler chicks on four diets containing 20.5, 21.7, 22.4 and $22.9 \mathrm{CP} \%$ from 1 to 45 days of age, found similar feed conversion ratios among all groups. Moreover, Stilborn et al. (1990) found that birds fed on diets containing 18 or $20 \%$ CP had similar feed conversion ratios. Daster and Golian (2003) indicated that broiler chicks fed on corn-soy diet containing 19\% CP or higher and supplemented with appropriate amounts of indispensable amino acids had similar feed conversion ratio compared to those fed a diet with $23 \% \mathrm{CP}$.

2-2-Effect of feed additives:-

Probiotics had significant effect $(P \leq 0.05)$ on feed intake of broiler chicks only during the first 3 weeks of age. Broiler chicks fed on the diets supplemented with Ronozyme consumed insignificantly higher $(\mathrm{P}<0.05)$ amounts of feed compared to those fed on the control diets. The increase in feed intake during the first 3 weeks of age in response to the addition of Ronozyme into broiler chick diets may be due to that its composite enzymes reduced the residence time of digesta in the gastrointestinal tract coincided with an improved nutrient digestibility (Adams, 1995). Those results agree with these reported by Friesen et al. (1992), Esteve garcia et al. (1997) and Alam et al. (2003) who indicated that enzymes and probiotics can increase feed intake in broiler chicks.

On the other hand, addition of probiotics into broiler chicks diet improved $(P<0.05)$ feed conversion ratios during the starting, growing and whole experimental periods. The improvements in feed conversion ratios in response to the addition of Ronozyme, Biomin or Super Bio Action were $14.62 \%, 14.57 \%$ and $17 \%$, respectively, during the entire experimental period. The beneficial effect of feed supplements (enzymes or probiotic) on feed conversion ratio may be due to a lower viscosity of intestinal contents and to an improvement in nutrients digestibility in the plant-protein diets (Annison and Choct, 1991; Bedford, 1995). According to Bedford (2001) much of performance response is thought to be related to the change in the intestinal microflora, rather than to a direct effect of enzyme on diet digestibility. Moreover, the beneficial effect of probiotic which contain Lactobacillus acidophilus on the performance of broiler chicks may be mediated by a direct antagonistic effect against specific groups of pathogenic micro-organisms, resulting in a decrease in their number (Hentges ,1983) or by increasing the immunity (Umesb, 1999). Noy and Sklan (1994) indicated that beneficial effects of enzyme addition to broiler diets are likely related to an increase in the rate of diet digestibility and production of simple-sugars (from fiber degradation). As a result of such improvements in the diet digestibility there is a significant change in the substrate quality and quantity available to the intestinal microflora in both the upper and lower gut. Hussein and El-Ashry 
Osman, A. M. A. et al.

(1991) indicated that the improvement in feed conversion ratio observed by Lactobacillus supplementation was mainly due to the improvement in the gastrointestinal conditions against the pathogenic bacteria which invade the digestive tract.

Table (4): Means of feed intake and feed conversion ratio of broiler chicks as affected by nutrient level and type of feed supplement during the experimental period.

\begin{tabular}{|c|c|c|c|c|c|c|}
\hline \multirow{3}{*}{ Treatments } & \multicolumn{3}{|c|}{ Feed intake (g) } & \multicolumn{3}{|c|}{ Feed conversion } \\
\hline & \multicolumn{3}{|c|}{ Age (wks) } & \multicolumn{3}{|c|}{ Age (wks) } \\
\hline & $0-3$ & $3-6$ & $0-6$ & $0-3$ & $3-6$ & $0-6$ \\
\hline Nutrient level & NS & $\star *$ & $\star *$ & * & NS & NS \\
\hline Control & 855.00 & $1374.42 c$ & $2142.7 b$ & $1.730 b$ & 1.862 & 1.723 \\
\hline Low C.P. & 880.00 & $1435.41 b$ & $2174.1 b$ & $1.786 a$ & 1.925 & 1.803 \\
\hline Low M.E. & 887.50 & $2016.26 a$ & $2859.7 a$ & $1.800 a$ & 1.850 & 1.756 \\
\hline SE & 0.123 & 0.0158 & 40.13 & 0.015 & 0.029 & 0.038 \\
\hline Feed additive: & $\star *$ & NS & NS & $* *$ & ** & $* *$ \\
\hline Control & $846.66 \mathrm{~b}$ & 1584.11 & 2447.2 & $1.925 a$ & $2.096 a$ & $1.990 a$ \\
\hline Ronozyme & $928.33 a$ & 1621.27 & 2441.3 & $1.739 b$ & $1.821 \mathrm{~b}$ & $1.699 b$ \\
\hline Biomin & $875.00 \mathrm{~b}$ & 1639.28 & 2379.7 & $1.741 b$ & $1.815 b$ & $1.70 \mathrm{~b}$ \\
\hline Super-Bio-Action & $846.66 \mathrm{~b}$ & 1590.13 & 2300.4 & $1.696 b$ & $1.785 b$ & $1.65 b$ \\
\hline SE & 12.48 & 0.0152 & 46.34 & 0.0158 & 0.030 & 0.042 \\
\hline Interaction & NS & $\star$ & NS & NS & NS & NS \\
\hline Control-without & 806.66 & $1428.33 b$ & 2156.7 & 1.884 & 2.133 & 1.952 \\
\hline Control-Ronozyme & 911.66 & $1376.83 b$ & 2166.7 & 1.731 & 1.819 & 1.684 \\
\hline Control-Biomin & 905.00 & $1350.86 a$ & 2147.7 & 1.715 & 1.755 & 1.654 \\
\hline Control-Superb & 796.66 & $1341.66 c$ & 2100.0 & 1.590 & 1.752 & 1.601 \\
\hline Low-C.P-Without & 893.33 & $1616.66 \mathrm{~b}$ & 2333.3 & 1.955 & 2.183 & 2.123 \\
\hline Low-C.P-Ronozyme & 930.00 & $1393.33 b$ & 2196.7 & 1.711 & 1.812 & 1.676 \\
\hline Low-C.P-Biomin & 850.00 & $1398.33 b$ & 2063.3 & 1.782 & 1.840 & 1.712 \\
\hline Low-C.P-Superbio & 846.66 & $1333.33 c$ & 2013.0 & 1.735 & 1.866 & 1.703 \\
\hline Low-M.E-Without & 840.00 & $1707.33 b$ & 2850.7 & 1.935 & 1.983 & 1.900 \\
\hline Low- M.E -Rononzy & 943.33 & 2093.66b & 2960.7 & 1.775 & 1.832 & 1.740 \\
\hline Low- M.E -Biomin & 870.00 & $2168.66 b$ & 2928.0 & 1.725 & 1.849 & 1.736 \\
\hline Low- M.E Superbio & 896.66 & $2095.40 b$ & 2698.3 & 1.764 & 1.738 & 1.656 \\
\hline SE & 98.32 & 101.7 & 80.26 & 0.124 & 0.142 & 0.073 \\
\hline
\end{tabular}

For each main factor, means within the same column bearing different letter (s) differ significantly ( $P<0.05$ )

\section{3-Viability:}

Neither diet nor probiotics had significant effect on viability of broiler chicks during the entire experimental period. These results coincide with those reported by Abd El-Fattah (2002) who illustrated that diet density had insignificant effect on viability rate of broiler chicks from one-day up to 6 weeks of age. Also, Alam et al. (2003) and Huang et al. (2004) found that probiotic had insignificant effect on the mortality rate of broiler chicks.

\section{4-Cost of feed $/ \mathbf{k g}$ gain and economic returns}

4-1-Effect of nutrient level:

Cost of feed (LE) per $\mathrm{Kg}$ gain and economic returns of broiler chicks as affected by diets and probiotics at 6 weeks of age are illustrated in Table 5 . Broiler chicks fed on the low-ME diets achieved lower $(P<0.05)$ cost of feed $/ \mathrm{kg}$ gain than those fed on the low-CP diets. The highest feed cost/bird was achieved by birds fed on the low-ME diets, however, they attained the best 
$(\mathrm{P}<0.05)$ economic return compared to those fed on the control or low-CP diets. The economic efficiency for birds fed the low-ME diets at marketing age were $34.4 \%$ and $40.56 \%$ greater than those fed on the control or low-CP diets, respectively. This could be attributed to the higher body weight gain (Table, 3) for broiler chicks fed the low-energy diets compared to those fed the control or low-CP diets. Also, broiler chicks fed on the control diets recorded insignificant better economic efficiency by about $4.4 \%$ compared to those fed the low-CP diets.

Table (5): Cost of feed (LE) $/ \mathrm{Kg}$ gain and economic return of broiler chicks as affected by nutrient level and type of feed supplement

\begin{tabular}{|c|c|c|c|c|c|c|c|}
\hline \multirow[t]{2}{*}{ TREATMENT } & \multicolumn{2}{|c|}{$\begin{array}{c}\begin{array}{c}\text { PRICE OF DIETS } \\
\text { (LE / / g })\end{array} \\
\end{array}$} & \multicolumn{2}{|c|}{$\begin{array}{c}\text { COST OF DIETS } \\
\text { PER }\end{array}$} & \multirow[t]{2}{*}{$\begin{array}{l}\text { PERICE / } \\
\text { BIRD }\end{array}$} & \multicolumn{2}{|c|}{$\begin{array}{l}\text { ECONOMIC } \\
\text { EFFICIENCEY }\end{array}$} \\
\hline & Starter & Grower & Kg gain & Bird & & Return & $\%$ \\
\hline Nutrient level & --- & -- & * & $\star *$ & $\star \star$ & $\star \star$ & -- \\
\hline Control & 1.890 & 1.899 & $3.24 a b$ & $4.12 b$ & $9.38 b$ & $5.26 b$ & 100 \\
\hline Low-C.P & 1.850 & 1.914 & $3.32 a$ & $4.08 b$ & $9.12 b$ & $5.03 b$ & 95.6 \\
\hline Low-M.E & 1.770 & 1.960 & $3.05 b$ & $5.17 a$ & $12.24 a$ & $7.07 a$ & 134.4 \\
\hline SE & ----- & --- & 0.07 & 0.08 & 0.25 & 0.21 & --- \\
\hline Feed additives: & & --- & $\star *$ & NS & $\star \star$ & $\star \star$ & --- \\
\hline Control & 1.838 & 1.850 & $3.58 a$ & 4.50 & $9.30 \mathrm{~b}$ & $4.81 b$ & 100 \\
\hline Ronozyme & 1.853 & 1.861 & $3.08 b$ & 4.52 & $10.75 a$ & $6.23 a$ & 129.5 \\
\hline Biomin & 1.904 & 1.907 & $3.16 \mathrm{~b}$ & 4.52 & $10.47 a$ & $5.94 a$ & 123.5 \\
\hline Superbio-action & 1.856 & 1.864 & $2.99 b$ & 4.27 & $10.44 a$ & $6.17 a$ & 128.3 \\
\hline SE & -- & --- & 0.027 & 0.23 & 0.56 & 0.33 & --- \\
\hline Interaction & ---- & ---- & NS & NS & NS & NS & ----- \\
\hline Control-Without & 1.895 & 1.899 & 3.62 & 4.09 & 8.28 & 4.18 & 100 \\
\hline Control-Ronozy & 1.910 & 1.914 & 3.17 & 4.14 & 9.64 & 5.50 & 131.5 \\
\hline Control-Biomin & 1.961 & 1.960 & 3.19 & 4.21 & 9.74 & 5.53 & 132.3 \\
\hline Control-Superbi & 1.914 & 1.913 & 2.97 & 4.01 & 9.83 & 5.81 & 139.3 \\
\hline Low-C.P-Without & 1.850 & 1.860 & 3.87 & 4.33 & 8.35 & 4.02 & 96.2 \\
\hline Low-C.P-Ronzym & 1.860 & 1.870 & 3.07 & 4.09 & 9.82 & 5.72 & 136.8 \\
\hline Low-C.P-Biomin & 1.910 & 1.930 & 3.22 & 3.96 & 9.04 & 5.07 & 121.8 \\
\hline Low-C.PSuperbi & 1.864 & 1.880 & 3.11 & 3.49 & 9.26 & 5.31 & 127.0 \\
\hline Low-M.E-Without & 1.770 & 1.790 & 3.26 & 5.08 & 11.29 & 6.20 & 148.3 \\
\hline Low-M.E-Ronozy & 1.790 & 1.800 & 3.01 & 5.32 & 12.78 & 7.46 & 178.5 \\
\hline Low-M.E-Biomin & 1.840 & 1.850 & 3.06 & 5.40 & 12.64 & 7.23 & 173.0 \\
\hline Low-M.E-Superbio & 1.790 & 1.800 & 2.88 & 4.84 & 12.23 & 7.37 & 176.3 \\
\hline SE & -- & --- & 0.021 & 0.027 & 0.052 & 0.051 & -- \\
\hline
\end{tabular}

For each main factor, means within the same column bearing different letter (s) differ significantly $(P<0.05)$

\section{4-2-Effect of feed additives:-}

Probiotics supplementation into broiler chicks diet decreased $(P<0.05)$ the cost of feed $/ \mathrm{kg}$ gain and improved $(P<0.05)$ the economic return by about $29.5 \%, 23.5 \%$ and $28.3 \%$ due to supplemental Ronozyme, Biomin and Super Bio-Action respectively, as compared to the control diets. This could be attributed to the higher body weight gain (Table, 3) and better feed conversion ratio attained by broiler chicks fed the supplemented diets compared to those fed the control diets. These results are coincided with the results reported by Kamaran et al. (2002), who indicated that enzyme supplementation into broiler chick diets improved their economic efficiency. 
Moreover, Hussein and El-Ashry (1991) found that dietary supplementation with Lactobacillus decreased the cost per $\mathrm{kg}$ live weight of chicks by $17.3 \%$ CP compared to a control group.

\section{5-Carcass traits:}

\section{5-1-Effect of nutrient level:}

Means of carcass traits in broiler chicks as affected by diet and probiotics are illustrated in Table 6 . Broiler chicks fed the low-ME diets had higher $(P<0.05)$ carcass weight compared to those fed the control or low-CP diets. This could be attributed to the close relationship between fasting body weight and carcass weight. Krapoth (1987) and Saleh (1992) found a strong correlation coefficient which fluctuated from $r=0.92$ to $r=0.98$ between body weight and carcass weight. Diet had insignificant effect on dressing\% where the values of dressing\% ranged between $75.79 \%$ to $78.55 \%$. Similar trend was noticed in giblets \%. As it was expected, broiler chicks fed on the low-ME diets had lower $(P<0.05)$ abdominal fat \% compared to those fed on the lowCP diets. Similar results were reported by Mahapatara et al. (1984). Diamabra and McCarteny (1985) who found that male broilers fed 9 and $15 \%$ CP diets had significantly more fat than those fed 12 and $18 \%$ protein-diets. Choudhary and Aggarwal (1987) reported a positive relationship between dietary protein level and carcass weight of broiler chicks, but dressing \% was not significantly affected by early protein restriction. Fancher and Jensen (1989) observed higher abdominal fat deposition when broiler chicks were fed lower levels of dietary crude protein during the growing period. Similar results were reported by Bunchasak et al. (1996) during the starting period. Also, Hai and Blaha (1998) indicated that, the low protein diets had little effect on dressing \%, but increased the abdominal fat content when offered to broiler chickens during the finishing period (from 21 to 42 days of age). Moreover, Barbour et al. (1999) found an inverse relationship between dietary ME content and abdominal fat pad size of broiler chicks raised from 0 to 7 weeks of age.

\section{5-2-Effect of feed additives:-}

Feed additives had highly significant $(P<0.01)$ effect on fasting body weight and carcass weight, while dressing, abdominal fat, liver, heart ,gizzard and giblets percentages at 6 week of age were not significantly affected by the addition of probiotics. Broiler chicks fed on diets with supplementary Ronozyme or Super Bio-Action had significantly $(p<0.05)$ higher fasting body weight and carcass weight compared to the unsupplemented control diets. However, broiler chicks fed on diets with supplemental Biomin had an intermediate fasting body weight and carcass weight at 6 weeks of age. Dressing\% was not significantly affected by the addition of probiotics which was within the normal range. Also, addition of probiotics into broiler chick diets had no detrimental effects on the accumulation of abdominal fat in the carcass. Similar trend was also observed in liver, heart, gizzard and giblets percentages. The effects of interaction (Diets $x$ Probiotics) on carcass traits were not significant.

Also, the effects of probiotic on carcass traits were not dependant on the type of diet. The higher chicks carcass weight observed with the supplemented-diets was attributed to the improvement in fasting body weight. 
It is well known that there was a strong relationship between fasting body weight and carcass weight (Krapoth, 1987; Saleh, 1992). The present results are in agreement with the findings reported by Aly (1993), Zanella et al. (1999), Panda et al. (2000) and Kamran et al. (2002), who indicated that probiotic had insignificant effects on dressing \%. Also, similar insignificant effects of probiotic on carcass yield were reported by (Esteve-garcia et al. 1997; Biswas et al. 1999; Kumprechtova, 1999) abdominal fat \% (EsteveGarcia et al. 1997; Zanella et al. 1999; Loddi et al. 2000) or the weights of internal organs (Aly, 1993; Panda et al., 2000).

\section{6-Some digestive tract measurements :}

\section{6-1-Effect of nutrient level:}

Means of weight, length and density of the digestive tract in broiler chicks as affected by diets and probiotics are presented in Table 7. Broiler chicks fed on the low-CP diets recorded the highest $(P<0.05)$ relative weight and length of duodenum compared to those fed on the control or the low-ME diets. However, those fed low-ME diets achieved the lowest $(P<0.05)$ relative length of small intestine and cecum and lowest relative weight and length of large intestine compared to those fed on the control or low-CP diets. The lowME diets increased $(P<0.05)$ the density of cecum. From these results it could be noticed that broiler chicks were capable to adapt themselves to the alterations in diet formulations by increasing or decreasing the relative weight and length or the density of different parts of the digestive tract. Moreover, changes in the digestive tract parameters were more pronounced by lowering the ME level rather than by decreasing the CP content of the diet. These results agree with the findings of Osman et al. (1996), who reported that the relative weight of digestive tract and cecum length were increased when Pekin ducklings were fed on a non-conventional diet, which had higher level of crude fiber. Also, Swatson et al. (2000) found that increasing the level of protein in the diet increased significantly the empty weight of ileum and ceca. Moreover, duodenal weight varied significantly with the change in dietary protein level. Abd El-Fattah (2002) indicated that the relative length of small intestine of broiler chicks was increased progressively with decreasing density of diet. $\mathrm{He}$ found also that the effect of lowering ME on the relative length of small intestine was more remarkable than the effect of lowering the crude protein content of the diet.

\section{6-2-Effect of feed additives:-}

Probiotics had significant effect $(P<0.05)$ only on the relative length of small intestine and density of large intestine. Broiler chicks fed on the diets supplemented with Biomin or Super Bio-Action recorded lower $(\mathrm{P}<0.05)$ relative length of small intestine compared to those fed on the nonsupplemented control diets.

The density of large intestine was increased $(P<0.05)$ by the addition of Ronozyme or Super Bio-Action into broiler chick diets. While the density of large intestine was unchanged by the supplementation of diets with Biomin. The relative weight and length of duodenum and cecum and the relative weight of small intestine were insignificantly decreased in response to feed supplements used. 
Osman, A. M. A. et al.

Table (6): Means of carcass traits in broiler chicks as affected by nutrient level and feed supplements.

\begin{tabular}{|c|c|c|c|c|c|c|c|c|}
\hline TREATMENTS & $\begin{array}{c}\text { fasting } \\
\text { body } \\
\text { weight (g }\end{array}$ & $\begin{array}{c}\text { Carcass } \\
\text { weight } \\
\text { (g) }\end{array}$ & $\begin{array}{c}\text { Dressing } \\
\%\end{array}$ & $\begin{array}{l}\text { Abdomina } \\
\text { fat } \%\end{array}$ & $\begin{array}{c}\text { Liver } \\
\%\end{array}$ & $\underset{\%}{\text { Gizzard }}$ & $\begin{array}{c}\text { Heart } \\
\%\end{array}$ & $\underset{\%}{\text { Giblet }}$ \\
\hline Nutrient level & & & NS & $* *$ & NS & * & NS & NS \\
\hline Control & $1309 \mathrm{~b}$ & $929 \mathrm{~b}$ & 75.79 & $1.70 \mathrm{~b}$ & 2.24 & $2.11 \mathrm{a}$ & 0.55 & 4.92 \\
\hline Low-C.P & $1255 b$ & $889 b$ & 77.03 & $2.94 \mathrm{a}$ & 2.29 & $2.13 a$ & 0.59 & 5.02 \\
\hline Low-M.E & 1598 a & $1176.6 a$ & 78.55 & $1.77 \mathrm{~b}$ & 2.47 & $1.80 \mathrm{~b}$ & 0.61 & 4.87 \\
\hline SE & 31.93 & 26.57 & 1.06 & 0.216 & 0.13 & 0.10 & 0.029 & 0.17 \\
\hline Feed additives: & $\star \star$ & $\star \star$ & NS & NS & NS & NS & NS & NS \\
\hline control & $1282.2 \mathrm{~b}$ & $810.2 b$ & 76.04 & 2.20 & 2.52 & 2.05 & 0.60 & 5.20 \\
\hline Ronozyme & $1471.1 \mathrm{a}$ & $1048.8 a$ & 75.79 & 2.02 & 2.32 & 1.82 & 0.54 & 4.69 \\
\hline Biomin & 1372ab & $994.8 \mathrm{ab}$ & 77.79 & 2.11 & 2.21 & 2.16 & 0.61 & 4.97 \\
\hline Super Bio-Action & 1425.1a & $1038.8 a$ & 77.58 & 2.20 & 2.28 & 2.02 & 0.60 & 4.89 \\
\hline SE & 36.87 & 30.68 & 1.22 & 0.25 & 0.15 & 0.11 & 0.03 & 0.20 \\
\hline Interaction & NS & NS & NS & NS & NS & NS & NS & NS \\
\hline Control-Without & 1178.6 & 802.6 & 73.36 & 1.69 & 2.23 & 2.33 & 0.53 & 5.11 \\
\hline Control-Ronozy & 1372.6 & 950.0 & 73.59 & 1.53 & 2.13 & 2.10 & 0.53 & 4.78 \\
\hline Control-Biomin & 1322.6 & 964.0 & 77.77 & 1.41 & 2.13 & 2.13 & 0.56 & 4.82 \\
\hline Control-Superbi & 1362.0 & 999.3 & 78.43 & 2.16 & 2.46 & 1.90 & 0.60 & 4.98 \\
\hline Low-C.P-Witho & 1260.0 & 876.0 & 74.56 & 3.16 & 2.43 & 2.03 & 0.60 & 5.12 \\
\hline Low-C.P-Ronzy & 1321.3 & 962.0 & 77.19 & 2.81 & 2.16 & 1.70 & 0.50 & 4.37 \\
\hline Low-C.P-Biomi & 1184.0 & 832.0 & 75.44 & 2.99 & 2.30 & 2.46 & 0.63 & 5.37 \\
\hline Low-C.PSuperi & 1258.0 & 886.0 & 75.42 & 2.76 & 2.26 & 2.33 & 0.63 & 2.21 \\
\hline Low-M.E-With & 1408.0 & 1052.0 & 80.19 & 1.73 & 2.90 & 1.80 & 0.66 & 5.37 \\
\hline Low-M.E-Rono & 1719.3 & 1234.6 & 76.59 & 1.72 & 2.66 & 1.66 & 0.60 & 4.91 \\
\hline Low-M.E-Bioin & 1609.3 & 1188.6 & 78.53 & 1.93 & 2.20 & 1.90 & 0.63 & 4.71 \\
\hline Low-M.E-Supb & 1655.3 & 1231.3 & 78.91 & 1.68 & 2.13 & 1.83 & 0.56 & 4.49 \\
\hline CE & 63.86 & 53.14 & 2.12 & 0.43 & 0.26 & 0.20 & 0.05 & 0.35 \\
\hline
\end{tabular}

For each main factor, means within the same column bearing different letter (s) differ significantly ( $\mathrm{P} \leq 0.05)$

Table (7): Means of empty weight\%, length\% and density (weight $(\mathrm{g}) /$ length $(\mathrm{cm})$ of certain parts of digestive tract in broiler chicks as affected by nutrient level and feed supplements.

\begin{tabular}{|c|c|c|c|c|c|c|}
\hline \multirow[t]{2}{*}{ TREATMENT } & \multicolumn{3}{|c|}{ Duodenum } & \multicolumn{3}{|c|}{ Small intestine } \\
\hline & Weight $\%$ & Length\% & $\begin{array}{l}\text { Density } \\
\text { g/cm }\end{array}$ & Weight $\%$ & Length $\%$ & $\begin{array}{c}\text { Density } \\
\mathrm{g} / \mathrm{cm}\end{array}$ \\
\hline Nutrient level & $\star \star \star$ & $\star \star$ & NS & NS & $\star \star *$ & NS \\
\hline Control & $0.62 b$ & $2.14 \mathrm{~b}$ & 0.32 & 2.43 & $9.91 \mathrm{a}$ & 0.24 \\
\hline Low-C.P & $0.91 a$ & $2.45 a$ & 0.36 & 2.78 & $10.49 a$ & 0.26 \\
\hline $\begin{array}{l}\text { Low-M.E } \\
\text { SE }\end{array}$ & $\begin{array}{c}0.66 \mathrm{~b} \\
0.02\end{array}$ & $\begin{array}{l}2.00 \mathrm{~b} \\
0.081\end{array}$ & $\begin{array}{l}0.32 \\
0.01\end{array}$ & $\begin{array}{l}2.48 \\
13.0\end{array}$ & $\begin{array}{l}8.87 b \\
0.271\end{array}$ & $\begin{array}{c}0.26 \\
0.009\end{array}$ \\
\hline Feed additives & NS & NS & NS & NS & * & NS \\
\hline Control & 0.84 & 2.37 & 0.35 & 3.27 & $10.48 a$ & 0.25 \\
\hline Ronozyme & 0.74 & 2.11 & 0.35 & 2.41 & $9.27 \mathrm{ab}$ & 0.26 \\
\hline Biomin & 0.73 & 2.22 & 0.32 & 2.41 & $9.90 \mathrm{~b}$ & 0.24 \\
\hline Super Bio-Action & 0.69 & 2.08 & 0.31 & 2.53 & $9.38 b$ & 0.27 \\
\hline SE & 0.05 & 0.93 & 0.01 & 15.0 & 0.314 & 0.01 \\
\hline Interaction & NS & NS & NS & NS & NS & NS \\
\hline cotrol-Without & 0.83 & 2.50 & 0.35 & 2.58 & 11.45 & 0.22 \\
\hline control-Ronozy & 0.63 & 2.12 & 0.33 & 2.47 & 9.45 & 0.27 \\
\hline cotrol-Biomin & 0.60 & 2.15 & 0.31 & 2.26 & 9.73 & 0.23 \\
\hline cotrol-Superbi & 0.55 & 1.77 & 0.30 & 2.43 & 9.04 & 0.27 \\
\hline Low-C.P-Without & 0.85 & 2.45 & 0.34 & 2.79 & 10.48 & 0.26 \\
\hline Low-C.P-Ronzym & 0.85 & 2.22 & 0.37 & 2.57 & 9.83 & 0.26 \\
\hline Low-C.P-Biomin & 0.95 & 2.62 & 0.35 & 2.61 & 11.31 & 0.22 \\
\hline Low-C.PSuperbi & 0.98 & 2.52 & 0.39 & 3.17 & 10.34 & 0.30 \\
\hline Low-M.E-Without & 0.81 & 2.16 & 0.37 & 2.77 & 9.50 & 0.28 \\
\hline Low-M.E-Ronozy & 0.69 & 2.00 & 0.34 & 2.20 & 8.56 & 0.26 \\
\hline Low-M.E-Biomin & 0.63 & 1.88 & 0.32 & 2.36 & 8.64 & 0.27 \\
\hline Low-M.E-Superb & 0.53 & 1.97 & 0.26 & 2.01 & 8.78 & 0.23 \\
\hline SE & 0.08 & 0.16 & 0.02 & 26.0 & 0.54 & 0.01 \\
\hline
\end{tabular}


J. Agric. Sci. Mansoura Univ., 32 (1), January, 2007

For each main factor, means within the same column bearing different letter (s) differ

Table 7 (continued)

\begin{tabular}{|l|c|c|c|c|c|c|}
\hline TREATMENT & \multicolumn{3}{|c|}{ Cecum } & \multicolumn{3}{|c|}{ Large intestine } \\
\cline { 2 - 7 } & Weight\% & Length\% & $\begin{array}{c}\text { Density } \\
\text { g/cm }\end{array}$ & Weight\% & $\begin{array}{c}\text { Length } \\
\%\end{array}$ & $\begin{array}{c}\text { Density } \\
\text { g/cm }\end{array}$ \\
\hline Nutrient level & $\mathrm{NS}$ & $\star *$ & $\star$ & $*$ & $\star *$ & $\mathrm{NS}$ \\
Control & 0.46 & $2.63 \mathrm{a}$ & $0.17 \mathrm{~b}$ & $0.17 \mathrm{a}$ & $0.59 \mathrm{a}$ & 0.29 \\
Low-C.P & 0.45 & $2.53 \mathrm{a}$ & $0.17 \mathrm{~b}$ & $0.18 \mathrm{a}$ & $0.65 \mathrm{a}$ & 0.28 \\
Low-M.E & 0.42 & $2.17 \mathrm{~b}$ & $0.19 \mathrm{a}$ & $0.15 \mathrm{~b}$ & $0.49 \mathrm{~b}$ & 0.29 \\
SE & 0.02 & 0.081 & 0.006 & 0.01 & 0.03 & 0.01 \\
\hline Feed additives & $\mathrm{NS}$ & $\mathrm{NS}$ & $\mathrm{NS}$ & $\mathrm{NS}$ & $\mathrm{NS}$ & $*$ \\
Control & 0.48 & 2.63 & 0.18 & 0.16 & 0.62 & $0.26 \mathrm{~b}$ \\
Ronozyme & 0.41 & 2.31 & 0.18 & 0.17 & 0.52 & $0.32 \mathrm{a}$ \\
Biomin & 0.43 & 2.42 & 0.17 & 0.16 & 0.56 & $0.26 \mathrm{~b}$ \\
Super-bio-action & 0.28 & 2.43 & 0.17 & 0.16 & 0.58 & $0.31 \mathrm{a}$ \\
SE & 0.03 & 0.94 & 0.007 & 0.86 & 0.03 & 0.015 \\
\hline Interaction & $\mathrm{NS}$ & $\mathrm{NS}$ & $\mathrm{NS}$ & $\star *$ & $\mathrm{NS}$ & $*$ \\
Control-Without & 0.53 & 2.86 & 0.18 & 0.17 & 0.64 & 0.27 \\
Control-Ronozy & 0.4 & 2.43 & 0.16 & 0.16 & 0.57 & 0.28 \\
Control-Biomin & 0.47 & 2.59 & 0.17 & 0.15 & 0.54 & 0.27 \\
Control-Superbi & 0.45 & 2.66 & 0.17 & 0.21 & 0.64 & 0.33 \\
Low-C.P-Without & 0.40 & 2.55 & 0.16 & 0.15 & 0.62 & 0.27 \\
Low-C.P-Ronzym & 0.40 & 2.35 & 0.17 & 0.15 & 0.52 & 0.28 \\
Low-C.P-Biomin & 0.46 & 2.63 & 0.17 & 0.21 & 0.70 & 0.30 \\
Low-C.PSuperbi & 0.48 & 2.62 & 0.18 & 0.19 & 0.63 & 0.31 \\
Low-M.E-Without & 0.51 & 2.47 & 0.20 & 0.16 & 0.59 & 0.27 \\
Low-M.E-Ronozy & 0.44 & 2.15 & 0.22 & 0.18 & 0.47 & 0.39 \\
Low-M.E-Biomin & 0.37 & 2.04 & 0.18 & 0.10 & 0.44 & 0.23 \\
SE Low-M.E-Superb & 0.35 & 2.01 & 0.17 & 0.15 & 0.48 & 0.29 \\
SE & 0.04 & 0.16 & 0.01 & 0.05 & 0.05 & 0.02 \\
\hline
\end{tabular}

For each main factor, means within the same column bearing different letter (s) differ significantly $(P \leq 0.05)$

Also, the effect of interaction (Diets $x$ probiotics) on the digestive tract measurements was insignificant. From these results, it could be noticed that the addition of such supplements into broiler chick diets had negligible effect on the measurements of digestive tract and their positive effects was not strong enough to induce changes in carcass yield. The present results are partially in agreement with those reported by Brenes et al. (1993) and Viveros et al. (1994) who found that enzyme addition decreased the digestive tract weight by $20 \%$ when expressed as a percentage of live weight. Fuente et al. (1995) indicated that empty weight of the intestinal tract was reduced by $5 \%$ by enzyme addition. They also showed that the empty weight of the intestinal tract was linearly related to digesta viscosity $(r=0.64)$ and this relationship was higher in broilers fed diets without enzyme $(r=0.90)$.

From these results, it could be concluded that the addition of probiotics into broiler chick diets improved fasting body weight and carcass weight with no adverse effects on carcass traits or quality. 


\section{REFERENCES}

Abd El-Fattah, M. A. (2002). Using some natural growth promoters in broiler diets. M.Sc. Thesis, Fac. Agric., Minia Univ.

Adams, C. A.(1995).Effect of commercial enzyme products for wheat-based broiler diets. Technical information first issue December 4.

Alam, M. J., M. A. R. Howlider, M. A. H. Pramanik and M. A. Haque. (2003). Effect of exogenous enzyme in diet on broiler performance. International J. Poult. Sci., 2 (2): 168-173.

Aly, A. A. S. (1993). Influence of enzyme preparation and growth promoters on broiler performance. Ph. D. Thesis, Fac. Agric. Cairo. Univ.

Annison, G., and M., Choct (1991). Anti nutritive activities of cereal non starch polysaccharides in broiler diets and strategies minimizing their effects .World's Poult. Sci. J. 47:232- 242.

Arram, G. A. (1984). The biological and physiological values of different rations in relation to body composition. Ph. D. Thesis, Fac. Agric, Cairo Univ.

Attia, A. I. (1999). Effect of dietary energy concentration with/without pronutrients on the performance of broiler chicks. Egyptian Journal of Nutrition and feeds. 2 (special issue): 665-676.

Babu, M., V. Sundararasu and P. Kothandaraman (1986). Studies on energy and protein requirements for broiler chickens. Nutr. Abstr. Rev. 57: 697.

Barbour, G.W.; M. T. Farran; M. G. Uwayjan and V. M. Ashkarian (1999). Effect of adding varying levels of oil in a corn- soybean meal diet on performance and carcass quality of broiler chickens. Poult. Sci., (Suppl. 1) $78: 53$ (Abstr. 235).

Bedford, M. R. (1995). Mechanism of action and potential environmental benefits from the use of feed enzymes. Anim. Feed. Sci. Technol., 53: 145-155.

Bedford, M.R. (2001). Enzymes, antibiotic and intestinal micro-flora. Feed Mic. vol., 9 number 2.

Biswas, T.; L. Mandal and S. K. Sarker (1999). Studies of enzymes supplementation and herbal preparation at different levels of energy on the performance of broilers. J. Interacademic, 3: 53-58.

Bougon, M. and M. Menec (1986). A study similar to field conditions, of different feeds of broiler chickens. Nutr. Abstr. Rev. 57: 632.

Brenes. A.; M. Smith; W. Guenter and R. R. Marquardt (1993). Effect of enzyme supplementation on the performance and digestive tract size of broiler chickens fed wheat and barley based diets. Poult. Sci., 72: 1731-1739.

Bunchasak, C.; K. Tanaka; S. Ohtani and C.M. Collado. (1996). Effect of Met+Cys supplementation to a low-protein diet on the growth performance and fat accumulation of broiler chicks at starter period. Animal Science and Technology, 67 (11): 956-966.

Choudhary, M. K. and C. K. Aggarwal (1987). Effect of early protein restriction on body measurements and meat quality of broilers. Indian Vet. J., 64 (5): 408-414. 
Daghir, N. J. (1983). Effect of lysine and methionine supplementation of low protein roaster diets fed after six weeks of age. Poult. Sci., 62 :1572 1575.

Daster, B. and A. Golian (2003). Pinpointing the lowest protein diet for young male broilers. (Nut. Gorgan, Iran Univ.).

Diamabra, O. H. and M. G. McCartney (1985). The effects of low protein finisher diets on broiler males' performance and abdominal fat. Poult. Sci., 64: 2013-2015.

Duncan, D. B. (1955). Multiple range and multiple $F$ tests. Biometrics $11: 1-42$

Esteve-garcia, E.; J. Brufau; A. Pérez -Vendrell; A. Miquel and K. Duven (1997). Bioefficacy of enzyme preparations containing $\beta$-glucanase and xylanase activities in broiler diets based on barley or wheat, in combination with flavomycin. Poult. Sci., 76: 1728-1737.

Fancher, B. I. and L. S. Jensen (1989). Influence on performance of three to six-week old broilers of varying dietary protein contents with supplementation of essential amino acid requirements. Poult. Sci., 68: 113-123.

Friesen O. D.; W. Guenter; R. R. Marquadt and B. A. Rotter (1992). The effect of enzyme supplementation on the apparent metabolizable energy and nutrient digestibilities of wheat, barley, oats, and rye for the young broiler chick. Poult. Sci., 71: 1710-1721.

Fuente, J. M.; P. Pérez de Ayala, A. Flores and M. J. Villamind (1998). Effect of storage time and dietary enzyme on the metabolisable energy and digest viscosity of barley-based diets. Poult . Sci., 77: 90-97.

Garcia Neto, M., G. M Pesti and R.I. Bakalli ( 2000). Influence of dietary protein level on the broiler chicken's response to methionine and betanie supplements. Poult. Sci., 79: $1478-1484$.

Haddadin, M. S. Y.; S. M. Abd El-Rahim; N. H. Odelailah and R. K. Robinson (1997). Aproposed protocol for checking the suitability of Lactobacillus acidophilus cultures for use during feeding trials with chickens. Tropical. Sci., 37: 16-20.

Hai, D. T and J. Blaha. (1998). The effect of low-protein diets with supplementation of essential amino acids on broiler chicken performance. Agric. Tropic. Subtropic., 31: 109- 116.

Hentges, D. J. (1983). Role of the intestinal micro flora in host defense against infection. In Human Intestinal Micro-flora in Health and Disease, edited by Hentges, D. J., pp. 311-331, Academic Press, New York.

Huang, M. K.; Y. J. Choi; R. Houde; J.-W. Lee; B. Lee and X. Zhao (2004). Effects of Lactobacilli and an acidophilic Fungus on the production performance and immune responses in broiler chickens. Poult. Sci., 83:788-795.

Hussein H. H. and M. A. El Ashry. (1991). Some studies on the beneficial effects of Lactobacillus concentrate supplementation on broiler performance . Egypt. J. Anim. Prod., 28 (1): 85-93.

Kamran. M, T. N. Pasha, A. Mahmud and Z. Ali (2002). Effect of commercial enzyme (Natugrain) supplementation on the nutritive value and inclusion rate of guar meal in broiler rations.

International J. Poult. Sci., 1 (6): 167-173. 
Krapoth, H. J. (1987). Unter suchungen zur schlacht-koeperbewertung und fleisch bed chaffenheit bei broiler. Ph .D .Thesis kiel university ,Germany.

Kumprechtova, D. (1999). Effect of continuous administration of selected probiotic preparations on chicken broiler performance and nitrogen output in droppings). Mendel University of Agriculture. and Forestry Brno, 127p. Dissertation thesis. Text in Czech.

Loddi M. M., E. Gonzales, T. S. Takita and A. A. Mendes (2000). Effect of the use of probiotic and antibiotic on performance yield and carcass quality of broilers. Revista Brasileira de Zootecnia 29 (4) : 1124 - 1131.

Mahapatara, C. M., N. K. Pandey and S. S. Verma (1984). Effect of diet, strain and sex on the carcass yield and meat quality of broilers. Ind.J. Poult. Sci., 19 (4) : 236-240.

Moran, E. T. (1979). Carcass quality changes with the broiler chicken after dietary protein restriction during the growing phase and finishing period compensatory growth. Poult. Sci., 58, 1257-1270.

NRC; National Research Council (1994). Nutrient requirements of poultry. 9th revised edition (Washington, National Academy Press.).

Noy, Y. and D. Sklan (1994). Digestion and absorpition in the young chicks . Poult. Sci., 73: 366-373.

Osman, A. M. A.; M. A. H. Soliman and S. A. Abd El-Latif (1996). Evaluation of a non-conventional diet for growing Pekin ducklings. Egypt. Poult. Sci., 16 (Џ): 365-378.

Panda, A. K.; M. R. Reddy; S. V. Rao; M. V. L. N. Raju and N. K. Praharaj (2000). Growth, carcass characteristics, immune competence and response to Escherichia coli of broilers fed diets with various levels of probiotic. Archiv fur Geflugelkunde, 64 (4): 152 - 156.

Sailer, K. (1985). Nutzung kompesatorischer wachstumesffekte bei der production schwerer mastbroiler. Ph. D. Thesis, Hoenheim University, Germany.

Saleh, K. (1992). Comparative studies on the performance of some broiler hybrids under certain feeding systems . Ph. D. Thesis, Fac. Agric., Minia Univ..

SAS. (1994). SAS / STAT User's Guide: Statistics .Ver .6.04, fourth edition, SAS institute Inc., NC,USA.

Sklan, D. (2002). Development of the digestive tract of poultry. World's Poult. Sci. J., 57 (4): 415-428.

Sohair, A. I. A. (1984). Studies on the effect of feeding broiler on rations varying in calcium sources and level or containing different values of metabolizable energy and crude protein. Ph. D. Thesis. Fac. Agric. Cairo Univ.

Stilborn, H. L., Amy L. Izat and W. Waldoup. (1990). Lysine and crude protein requirements of male broilers from 3 to 6 weeks of age. Poult. Sci 69: 131 (Abstr.).

Swatson, H. K., R. M. Gous and P. A. lji (2000). Biological performance and gastrointestinal development of broiler chicks fed diets varying in energy : protein ratio. South African J.Anim. Sci., 30 (Supplement1).

Umesb, P. C. P. (1999). Probiotics benefits. Poultry International, 38 (12) : 40 -44 . 
Viveros, A., A. Brenes; A. M. Bizarro and M. Castano (1994). Effect of enzyme supplementation of a diet based on barley, and autoclave treatment, on apparent digestibility, growth performance and gut morphology of broilers. Anim. Feed Sci. Technol. 48: 237 - 251.

Watkins, B. A. and F. H. Kratzer (1984). Drinking water treatment with a commercial preparation of a concentrated Lactobacillus culture for broiler chickens. Poult. Sci., 63:1671-1673.

Yeo. J. and K. I. Kim (1997). Effect of feeding diets containing an antibiotic, or yucca extract on growth and intestinal urease activity in broiler chicks. Poult. Sci., $76:$ 381-385.

Zanella. I, N. K. Sakomura, F. G. Silversides, A. Fiqueirdo and M. Pack (1999). Effect of enzyme supplementation of broiler diets based on corn and soybeans. Poult. Sci., $78: 561-568$.

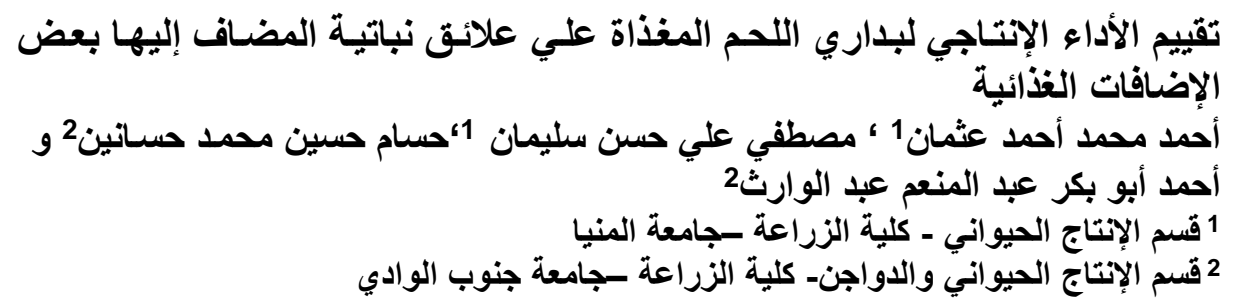

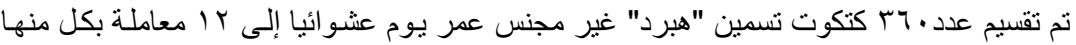

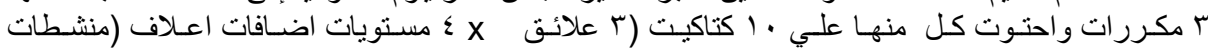

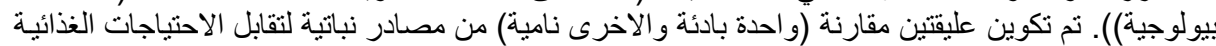

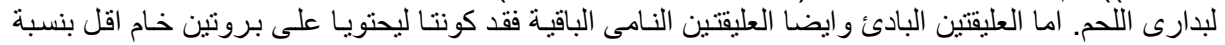

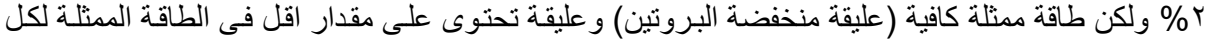

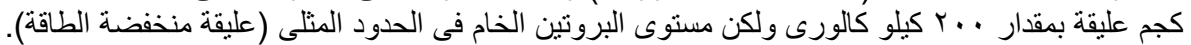

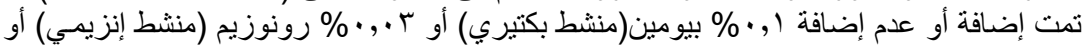

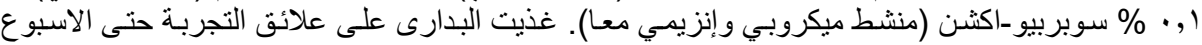

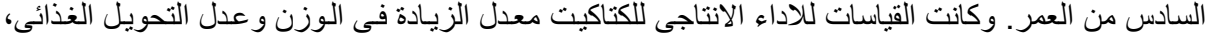

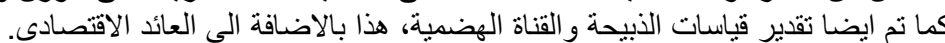

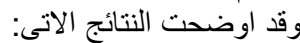

ـ حققت الطيور المغذاة علي العليقة المنخفضة في الطاقة اعلى وزن جسم عند عمر بأسابيع وكذلك أعلى معدل

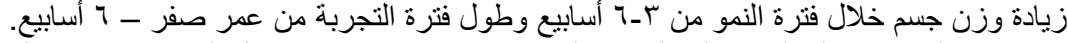

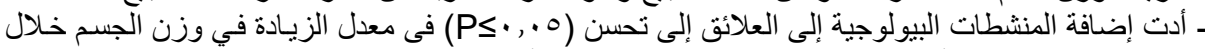

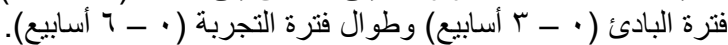

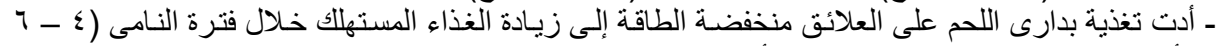

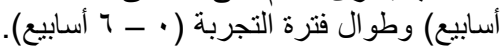

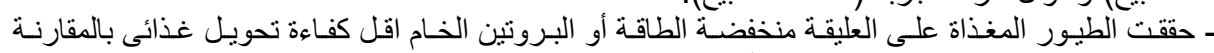

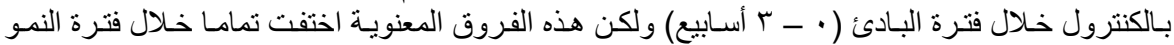

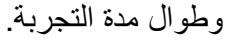

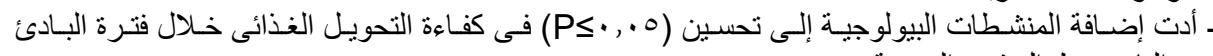
و النامى وطو ال فترة التجربة.

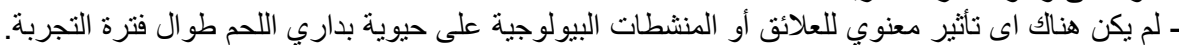

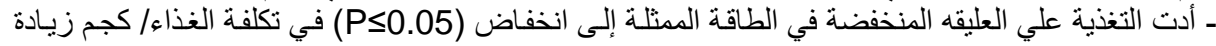
في وزن الطائر مقارنة بالتغذية علي العليقه المنففضـة في البروتين. بينما تحقق اعلى سعر بيع للطائر 
Osman, A. M. A. et al.

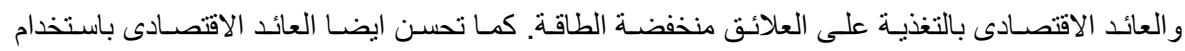
الاضافات الغذائية.

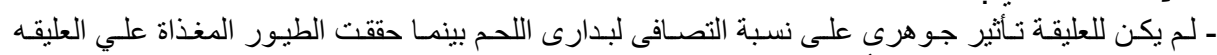

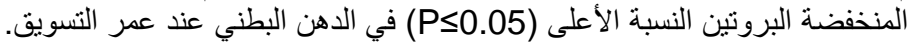

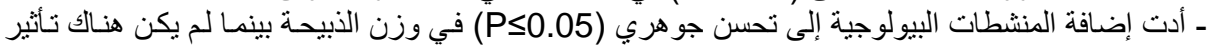

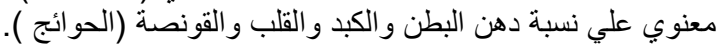

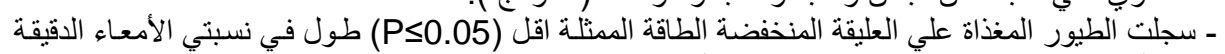

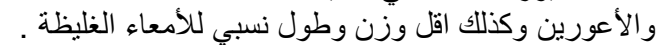

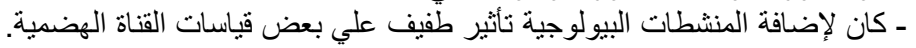

